Canadian

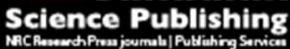

Applied Physiology, Nutrition, and Metabolism Physiologie appliquée, nutrition et métabolisme

\title{
Recent developments in understanding protein needs - How much and what kind should we eat?
}

\begin{tabular}{|r|l|}
\hline Journal: & Applied Physiology, Nutrition, and Metabolism \\
\hline Manuscript ID & apnm-2015-0549.R2 \\
\hline Manuscript Type: & Current opinion \\
\hline Date Submitted by the Author: & 08-Mar-2016 \\
\hline Complete List of Authors: & $\begin{array}{l}\text { Pencharz, Paul B.; The Hospital for Sick Children, Research Institute, Peter } \\
\text { Gilgan Centre for Research and Learning } \\
\text { Elango, Rajavel; University of British Columbia, Pediatrics } \\
\text { Wolfe, Robert; Univ. of Arkansas Medical School, Department of Geriatrics }\end{array}$ \\
\hline Keyword: & $\begin{array}{l}\text { protein recommendations, protein requirements, protein quality, optimal } \\
\text { protein intakes, growth }\end{array}$ \\
\hline
\end{tabular}




\title{
Recent developments in understanding protein needs -
}

\section{How much and what kind should we eat?}

\author{
Paul B. Pencharz ${ }^{\text {a,b }}$ (corresponding author) \\ Rajavel Elango ${ }^{\mathrm{c}, \mathrm{d}, \mathrm{e}}$ \\ Robert R. Wolfe ${ }^{\mathrm{f}}$
}

${ }^{a}$ Research Institute, The Hospital for Sick Children, 555 University Avenue, Toronto, ON, M5G 1X8, Canada, Email: paul.pencharz@sickkids.ca, Telephone: 416-813-6172, Fax: 416-813-4972.

${ }^{\mathrm{b}}$ Department of Paediatrics and Nutritional Sciences, University of Toronto

${ }^{\mathrm{c}}$ Department of Pediatrics, University of British Columbia

${ }^{\mathrm{d}}$ School of Population and Public Health, University of British Columbia

${ }^{\mathrm{e}}$ Child and Family Research Institute, BC Children's Hospital, Room 170A, 950 West $28^{\text {th }}$ Avenue, Vancouver, BC, V5Z 4H4, Canada, Email: relango@cfri.ubc.ca

${ }^{\mathrm{f}}$ Department of Geriatrics, Center for Translational Research in Aging and Longevity, Reynolds Institute on Aging, University of Arkansas for Medical Sciences, $4301 \mathrm{~W}$ Markham Street, \#806, Little Rock, AR, 72205, USA, Email: RWolfe2@uams.edu 


\begin{abstract}
A novel method has been developed to determine protein requirements, which is called

Indicator amino acid oxidation (IAAO). This technique has been validated by comparison with the "gold standard" nitrogen balance". Using IAAO we have shown that minimum protein requirements have been under estimated by $30-50 \%$. The National Academy of Sciences have for macro-nutrients proposed “Acceptable Macronutrient Distribution Ranges", which for protein is 10 to $35 \%$ of total energy. In practice, we suggest $1.5-2.2$ $\mathrm{g} / \mathrm{kg} / \mathrm{d}$ of a variety of high-quality proteins.
\end{abstract}




\section{Key Words}

Protein

Protein recommendations

Protein requirements

Amino acid requirements

Protein quality

Optimal protein intakes

Energy

Growth

Lean body mass 


\section{Introduction}

This brief synopsis highlights recent developments in understanding protein needs based on presentations at the 2015 Canadian Nutrition Society conference, Advances in Protein Nutrition across the Lifespan. Understanding of protein needs is based upon first defining the minimum amount required for health, which is described in the current Dietary Reference Intakes (DRI) by the terms estimated average requirement (EAR) and recommended dietary allowance (RDA) (Institute of Medicine 2005). The RDA is intended to cover minimum protein needs for $97.5 \%$ of the healthy population. Secondly, protein needs are based on defining the safe upper limits (UL). The Institute of Medicine (2005) report goes on, based on the first two steps, to define "Acceptable Macronutrient Distribution Ranges" (AMDR). The current AMDR for protein is 10 to 35\% of total energy for adults. The present review outlines the work published since the Institute of Medicine (2005) recommendations and is focused on a novel method to determine the minimum amount of protein required for health. The work presented covers only healthy human beings and ranges from school aged children to the elderly. The question of 'how much and what type of protein should we eat?' is also explored.

A review of current evidence on protein requirements to prevent age-related sarcopenia, promote healthy weight management and peak athletic performance also based on presentations at the 2015 Canadian Nutrition Conference on protein has been published by Phillips et al. (2016).

Until quite recently protein and amino acid requirements were determined using nitrogen balance (namely food nitrogen intake minus nitrogen excreted). The drawbacks with nitrogen balance are that a minimum of three days is needed per level of test intake 
and 7-10 days of adaptation are needed to each intake of protein or amino acid. In addition, complete collection and quantification of all sources of nitrogen excretion (mostly in urine and faeces) is difficult. More fundamentally, the nature of the calculation of nitrogen balance is likely to result in wide variability because nitrogen intake and nitrogen excretion are much larger numbers than the difference between them (i.e., nitrogen balance). Hence alternative methods have been developed based on carbon oxidation.

Currently, a suitable alternative is the indicator amino acid oxidation (IAAO) method (Elango et al. 2008a). Briefly, an essential amino acid (usually phenylalanine, lysine or leucine) is labeled with the stable isotope carbon-13 $\left({ }^{13} \mathrm{C}\right)$ and appearance of the label in breath carbon dioxide $\left({ }^{13} \mathrm{CO}_{2}\right)$ is used as an indicator of protein or amino acid requirement. Graded intakes of protein or amino acids are fed to the experimental subjects and a break-point is defined as a reflection of requirement. Adaptation of only 3 to 4 hours is needed since IAAO is dependent upon the rapidly turning over pools of tRNA-test amino acid from which proteins are synthesized (Elango et al. 2012). Evidence from the application of the IAAO technique in various groups suggests current recommendations substantially underestimate minimum protein requirements throughout the lifecycle.

\section{Protein and amino acid requirements}

In 1900 a German Scientist, Voit, reported the protein requirement as $1 \mathrm{~g} / \mathrm{kg} / \mathrm{d}$ based on what highly productive factory workers ate. The WHO Committees estimated mean protein requirements as $0.66 \mathrm{~g} / \mathrm{kg} / \mathrm{d}$ with a population requirement of $0.8 \mathrm{~g} / \mathrm{kg} / \mathrm{d}$, 
based on nitrogen balance data analyzed using mono-linear regression. A reanalysis of the published nitrogen balance data using two phased linear cross over analysis resulted in a mean requirement of $0.91 \mathrm{~g} / \mathrm{kg} / \mathrm{d}$ and a population estimate of $1.0 \mathrm{~g} / \mathrm{kg} / \mathrm{d}$ - identical to that of Voit 100 years earlier (Humayun et al. 2007). This estimate was confirmed using the carbon oxidation based method, IAAO, with a mean estimate of $0.93 \mathrm{~g} / \mathrm{kg} / \mathrm{d}$, essentially the same as the reanalysis of the nitrogen balance data (Humayun et al. 2007). Concern has been raised that this experimental design used a complete and balanced mixture of amino acid, instead of intact protein; and hourly meals, instead of standard meals every 4 h. An Asian Group (Tian et al. 2011) has conducted studies in young Chinese women using intact protein and meal feeding and applied the IAAO method to determine protein requirement. The results obtained for mean and population safe protein requirement of 0.91 and $1.09 \mathrm{~g} / \mathrm{kg} / \mathrm{d}$ are comparable to the estimates obtained by Humayun et al. (2007). Once it is appreciated that the dietary function of protein is to provide the 20 amino acids for which t-RNA exists (IOM 2005) the observation of Tian et al (2011) are not surprising. Studies in the elderly (Rafii et al. 2015; Tang et al. 2014) using the carbon oxidation approach obtained essentially identical estimates on a body weight basis.

During pregnancy, protein needs are different depending on the stage of gestation, with early stages requiring $1.2 \mathrm{~g} / \mathrm{kg} / \mathrm{d}$ and later stages of pregnancy requiring $1.5 \mathrm{~g} / \mathrm{kg} / \mathrm{d}$ (Stephens et al. 2015). Moreover, a mean protein requirement of $1.3 \mathrm{~g} / \mathrm{kg} / \mathrm{d}$ has been reported in pre-adolescent school-aged children (Elango et al. 2011). The protein intakes of economically challenged children are much less, around $0.9 \mathrm{~g} / \mathrm{kg} / \mathrm{d}$ and growth stunting is a major issue in the developing world. Feeding growing farm animals 
insufficient protein also results in growth restriction. Hence, there is strong evidence that protein needs in children have been underestimated by around $50 \%$ and results in marked growth retardation in the developing world (Elango et al. 2011; Elango et al. 2010). These observations have important implications for public health and world agriculture. Children living in the developing world also have a diet that is limiting in the essential amino acid lysine. It had been hypothesized that these populations may be able to adapt and thrive on a lower lysine intake than that needed in the developed world. To test this question, the lysine needs of school aged children in Toronto and in Bangalore, India were measured and shown to be identical (Pillai et al. 2010). Moreover, the lysine requirements in moderately malnourished Indian children increased by $20 \%$ due to gut parasite infection (Pillai et al. 2015). Thus, healthy children worldwide have similar lysine requirements, while the presence of gut parasites increases the need for lysine.

The non-invasive nature of the IAAO technique has also allowed for the study of amino acid needs in other vulnerable individuals. Thus, direct measurement of the limiting amino acids requirements in inborn errors of amino acid metabolism such as, phenylketonuria and maple syrup urine disease, have been obtained for the first time (Pencharz and Ball 2006). IAAO has also been used to determine requirements for branched chain amino acids which are increased in children with liver disease (Mager et al. 2006). This is useful since it makes the prevention of malnutrition and growth failure possible in children with chronic liver disease. Amino acid needs in premature infants, especially those needing parenteral nutrition, have yet to be completely defined. Amino acid requirements during pregnancy and lactation also need to be defined. 


\section{How much protein should we eat?}

Current dietary guidelines include a number of different recommendations for dietary protein (as outlined in supplementary Table S1). Lack of clarity and apparent contradictions in the current guidelines have resulted in uncertainty in practice. Some of the confusion may be alleviated by understanding the basis for the various recommendations and by re-labelling dietary guidelines in terms of the recommended minimal and flexible intake.

North American adult habitual protein intakes average $16 \%$ of energy $(1.68 \mathrm{~g} / \mathrm{kg} / \mathrm{d})$ and range up to $23 \%$ of energy $(2.4 \mathrm{~g} / \mathrm{kg} / \mathrm{d})$. These values are derived from the USDA and Health Canada data contained as supplementary table to the Institute of Medicine, Macronutrient DRI (2005). The concept of an acceptable macronutrient distribution range (ADMR) also comes from the Macronutrient DRI.

Current evidence indicates that most adults will benefit from intakes above the Recommended Dietary Allowance (RDA) of $0.8 \mathrm{~g}$ protein $/ \mathrm{kg} /$ day. The nitrogen balance approach used to determine the Estimated Average Requirement (EAR) of $0.66 \mathrm{~g}$ protein $/ \mathrm{kg} /$ day (and thus the RDA) defines a minimal level of protein intake needed to avoid a deficiency (Institute of Medicine 2005). This approach does not consider protein intake in relation to physiological functions responsive to the level of dietary protein intake, or the relation of protein to the intake of other macronutrients. Thus, although the RDA is often interpreted as a target for the desired level of intake, in reality it better reflects a minimal amount that will prevent symptoms of deficiency in most individuals.

It is important to remember that we eat protein in the context of complete meals. The DRI report also presents recommendations for macronutrient intakes as the 
Acceptable Macronutrient Distribution Range (AMDR). For the sake of easy comparison with the other values, the AMDR for protein of $10-35 \%$ of total caloric intake for adults can be converted into $\mathrm{g}$ protein/kg/day by assuming a caloric expenditure of 42 $\mathrm{kcal} / \mathrm{kg} /$ day and body weights of $57 \mathrm{~kg}$ for women and $70 \mathrm{~kg}$ for men (Institute of Medicine 2005). Based on this, the AMDR recommends a protein intake of 1.05 to 3.67 $\mathrm{g} / \mathrm{kg}$ /day for adults (i.e., well above the RDA). Analysis of the USDA "My Pyramid" reveals a recommended protein intake of $17-21 \%$ of caloric intake (Fulgoni 2008), or $1.78-2.20 \mathrm{~g} / \mathrm{kg} /$ day for the energy expenditure and body weight assumed in the DRIs.

\section{Beyond zero nitrogen balance}

When nitrogen intake exceeds the amount required to achieve zero nitrogen balance, a progressively positive nitrogen balance (i.e., nitrogen intake greater than nitrogen output) results. It has been assumed that positive nitrogen balance values in adults are artifacts and therefore not considered in the estimation of the EAR (Millward 2012), but the justification for ignoring positive values is largely that the results don't fit the pre-conceived model. However when the nitrogen balance data, collected from studies conducted around the world was reanalyzed (including that with positive balance) using two-phase linear regression cross over analysis to determine EAR and RDA; the mean calculated values were 0.93 and $1.2 \mathrm{~g}$ protein $/ \mathrm{kg} /$ day, respectively (Elango et al. 2010). These values were approximately 50\% higher than the corresponding values published in the DRI report.

Experimental results from a variety of sources indicate that net protein balance (i.e., protein synthesis minus protein breakdown) increases linearly as a function of 
amino acid availability (Deutz and Wolfe 2013). The principal response to an increase in dietary protein at levels below the EAR is an increase in net protein balance due to stimulation of protein synthesis. Rates of protein intake greater than the EAR not only stimulate protein synthesis, but progressively inhibit protein breakdown.

A number of outcome studies also suggest that dietary protein intake greater than the RDA may increase lean body mass and improve physical function. For example, supplementation of the normal diet twice per day with a mixture of essential amino acids equivalent to the amount in approximately $30 \mathrm{~g}$ of high-quality protein, without any alteration in normal dietary intake or exercise, increased lean body mass, strength, and functional test scores in free-living healthy elderly subjects (Børsheim et al. 2008; Dillon et al. 2009). Moreover, acute stimulation of muscle protein fractional synthetic rate by amino acids translated to a significant amelioration of the decline in functional status in healthy elderly that normally occurred after 10 days of enforced bed rest (Ferrando et al. 2010). Supplementation of the diet with the same mixture of amino acids, along with a small amount of carbohydrate, also decreased the extent of loss of lean body mass and muscle strength in response to enforced bed rest in healthy young subjects (Paddon-Jones et al. 2004). Increased protein intake has also been demonstrated to have beneficial effects on muscle mass in other studies in older adults (Chevalier et al. 2003).

\section{Estimating an optimal range of protein intakes for adults}

When estimating an optimal amount of dietary protein it is important to consider the composition of the entire diet. In an adult with a normal rate of energy expenditure (42 $\mathrm{kcal} / \mathrm{kg} /$ day) (Institute of Medicine 2005), the RDA for dietary protein meets less 
than $10 \%$ of caloric requirement. The balance of the diet must be composed of carbohydrate and fat (or alcohol). The beneficial effects of dietary protein and the potential adverse effects of excessive intakes of carbohydrate or fat, also suggest that the optimal level of protein intake exceeds the RDA for protein. The question is: exactly how much protein should we eat?

The caloric values of the RDAs for protein and carbohydrate, plus the recommended minimal fat intake sum to only about $40 \%$ of total caloric expenditure (Institute of Medicine, 2005). Thus, the complete diet can be thought of as consisting of two components: a minimal intake for protein, carbohydrate, and fat and the flexible intake that comprises the difference between the caloric values of the RDAs or minimal intake and total caloric intake. If just $10 \%$ of the flexible intake is protein, this would correspond to $0.7 \mathrm{~g} / \mathrm{kg} / \mathrm{d}$, added to the RDA of $0.8 \mathrm{~g} / \mathrm{kg} / \mathrm{day}$, for a total of $1.5 \mathrm{~g} / \mathrm{kg} / \mathrm{day}$. If $20 \%$ of the flexible intake is comprised of protein, this would correspond to $1.4 \mathrm{~g} / \mathrm{kg} / \mathrm{day}$, or a total protein intake of $2.2 \mathrm{~g} / \mathrm{kg} / \mathrm{day}$. These values represent conservative estimates of the optimal contribution of protein to the flexible intake of dietary calories, and fall well within the range of dietary protein intakes recommended by the AMDRs and the USDA Dietary Guidelines. There are no known adverse effects of this level of protein intake in normal individuals (Institute of Medicine 2005, Phillips et al. 2016). Therefore we propose that in practice, $1.5-2.2 \mathrm{~g} / \mathrm{kg} /$ day constitutes a reasonable recommendation for the amount of protein that should be eaten by adults as part of a complete diet.

\section{What type of protein should we eat?}

The assumption underlying recommendations for dietary protein is that it consists 
of "high-quality" protein. The term protein quality refers to the balance of the amino acids; the digestibility of the protein to release the amino acids for absorption; and the availability of the absorbed amino acids for protein synthesis. The case of lysine provides an example of the importance of considering the amount of amino acids available for metabolic processes, most notably protein synthesis. Cooking can denature lysine and hence make the absorbed lysine not available for protein synthesis (Food and Agriculture Organization 2013). The Digestible Indispensable Amino Acid Score recently proposed by the Food and Agriculture Organization (FAO, 2013) provides a more accurate estimate of protein quality, than the Protein Digestibility Corrected Amino Acid Score (PDCAAS), previously used to quantify protein quality. PDCAAS is based on the ratio of the first-limiting essential amino acid in the test protein to the reference protein. The values were truncated at 1 , although high quality proteins have PDCAAS well above 1 . The principal advantages of DIAAS are that (a) the true ileal digestibility of individual amino acids in the test protein is taken into account and (b) the values are not truncated. Values for DIAAS are expressed as the percent of the dietary requirement for each essential amino acid met by ingestion of $0.66 \mathrm{~g}$ of the test protein $/ \mathrm{kg} / \mathrm{day}$, and the lowest DIAAS is considered the DIAAS of the test protein. DIAAS scores for animal proteins such as milk, eggs, and beef are well above $100 \%$, whereas vegetable proteins generally fall below $80 \%$ with the exception of soy.

As stated by the FAO (2013) our current methods and understanding of protein quality in humans is very limited. Conversely, in agriculture, the protein quality of animal feeds is better understood. Hence, we are currently conducting studies in pigs and humans to develop more practical and valid methods to determine the quality of plant 
protein in humans (Elango et al 2012). Cereals protein are limited in lysine (all), threonine (most) and tryptophan (maize) and legumes are sufficient in lysine, threonine and tryptophan but are limited in sulphur amino acids. Hence complementation (mixtures) of cereals and legumes are being evaluated to determine how to achieve the best possible plant protein mixtures.

The discrepancies in quality between animal and plant proteins become dramatic when the energy equivalents of the food sources are accounted for in the expression of quality. Caloric requirement to meet essential amino acid requirements for plant proteins are considerably greater than required by the ingestion of animal proteins. This is an important consideration given that obesity and sarcopenia (i.e., loss of lean body mass with age) are two of today's largest public health challenges. As outlined by Phillips et al. (2016) protein intakes above the current RDA (within the AMDR) can help to improve satiety and support weight management efforts and may help to prevent age-related sarcopenia as people age and have no known adverse impacts on health. There is an urgent need to re-evaluate protein recommendations to ensure they reflect recent developments in understanding protein requirements.

\section{Take-home points}

- Recent evidence indicates the current RDAs substantially underestimate minimum protein requirements throughout the lifespan.

- The AMDR of 10 to $35 \%$ of calories from protein for adults allows considerable flexibility to recommend protein intakes above the current RDA.

- In practice, 1.5 to $2.2 \mathrm{~g} / \mathrm{kg} /$ day of high-quality protein constitutes a reasonable 
recommendation for adults as part of a complete diet.

- High-quality animal proteins require far less energy intake to meet essential amino acid needs than lower quality plant proteins.

\section{Acknowledgements}

This manuscript provides a brief synopsis of presentations given by the authors at the 2015 Canadian Nutrition Society thematic conference on Advances in Protein Nutrition Across the Lifespan. David Ma, PhD, Robert Bertolo, PhD and Valerie Johnson, MHSc, RD participated in the conception, writing, review and editing of this manuscript. Support for open access publication was provided by the Canadian Pork Council, Dairy Farmers of Canada and Egg Farmers of Canada.

\section{Author disclosure statements}

Paul Pencharz and Rajavel Elango declare that there are no conflicts of interest. Robert Wolfe has received research grants from Abbott, Baxter and the National Cattlemen's Beef Association. He has received honoraria for speaking from the National Cattlemen's Beef Association. 


\section{References}

Børsheim E., Bui, Q-U.T., Tissier, S., Kobayashi, H., Ferrando, A.A., and Wolfe, R.R. 2008. Effect of amino acid supplementation on muscle mass, strength and physical function in elderly. Clin. Nutr. 27(2): 189-195.

Chevalier, S., Gougeon, R., Nayar, K., and Morais, J.A. 2003. Frailty amplifies the effects of aging on protein metabolism: role of protein intake. Am. J. Clin. Nutr. 78(3): $422-429$.

Deutz, N.E., and Wolfe, R.R. 2013. Is there a maximal response to protein intake with a meal? Clin. Nutr. 32(2): 309-13.

Dillon, E.L., Sheffield-Moore, M., Paddon-Jones, D., Gilkison, C., Sanford, A.P., Casperson, S.L., Jiang, J., Chinkes, D.L., and Urban, R.J. 2009. Amino acid supplementation increases lean body mass, basal muscle protein synthesis, and insulinlike growth factor-I expression in older women. J. Clin. Endocrinol. Metab. 94(5): 16301637.

Elango, R., Ball, R.O., and Pencharz, P.B. 2008. Indicator amino acid oxidation: concept and application. J. Nutr. 138(2): 243-246.

Elango, R., Ball, R.O., and Pencharz, P.B. 2012. Recent advances in protein and amino 
acid requirements. Br. J. Nutr. 108(Suppl 2): S22-30.

Elango, R., Humayun, M.A., Ball, R.O., and Pencharz, P.B. 2010. Evidence that protein requirements have been significantly underestimated. Curr. Opin. Clin. Nutr. 13(1): 5257.

Elango, R., Humayun, M.A., Ball, R.O., and Pencharz, P.B. 2011. Protein requirement of healthy school-age children determined by indicator amino acid oxidation method. Am. J. Clin. Nutr. 94(6): 1545-1552.

Elango, R., Levesque, C., Ball, R.O., Pencharz, P.B. 2012. Available versus digestible amino acids - new stable isotope methods. Br. J. Nutr. 108:S306-314.

Ferrando, A.A., Paddon-Jones, D., Hays, N.P., Kortebein, P., Ronsen, O., Williams, R.H., McComb, A., Symons, T.B., Wolfe, R.R., and Evans, W. 2010. EAA supplementation to increase nitrogen intake improves muscle function during bed rest in the elderly. Clin. Nutr. 29(1): 18-23.

Food and Agriculture Organization of the United Nations. 2013. Dietary protein quality evaluation in human nutrition. Report of an FAO Expert Consultation. 31 March-2 April, 2011. FAO Food and Nutrition Paper 92.

Fulgoni VL 3rd. 2008. Current protein intake in America: analysis of the National Health 
and Nutrition Examination Survey. Am. J. Clin. Nutr. 87(5):1554S-1557S.

Humayun, M.A., Elango, R., Ball, R.O., and Pencharz, P.B. 2007. A re-evaluation of protein requirement in young men using the indicator amino acid oxidation technique. Am. J. Clin. Nutr. 86(4): 995-1002.

Institute of Medicine. Dietary reference intakes for energy, carbohydrates, fiber, fat, protein and amino acids (macronutrients). 2005; Washington, DC. The National Academies Press.

Mager, D.R., Wykes, L.J., Ball, R.O., Roberts, E.A., and Pencharz, P.B. 2006. Branched chain amino acid requirements in children with mild-moderate chronic cholestatic liver disease. J. Nutr. 136(1):133-139.

Millward, D.H. 2012. Identifying recommended dietary allowances for protein and amino acids: a critique of the 2007 WHO/FAO/UNU report. Br .J. Nutr. 108: S3-S21.

Paddon-Jones, D., Sheffield-Moore, M., Urban, R.J., Sanford, A.P., Aarsland, A., Wolfe, R.R., and Ferrando, A.A. 2004. Essential amino acid and carbohydrate supplementation ameliorates muscle protein loss in humans during 28 days bedrest. J. Clin. Endocrinol. Metab. 89(9): 4351-4358.

Pencharz, P.B., and Ball, R.O. 2006. Amino Acid requirements of infants and children. 
Nestle Nutrition Workshop Series Volume 58:109-119.

Phillips, S.M., Chevalier, S., and Leidy, H.J. 2016. Protein 'requirements' beyond the RDA: implications for optimizing health. Appl. Physiol. Nutr. Metab. (In Press).

Pillai, R.R., Elango, R., Muthayya, S., Ball, R.O., Kurpad, A.V., and Pencharz, P.B. 2010. Lysine requirement of healthy Indian school-aged children determined by the indicator amino acid oxidation technique. J. Nutr. 140(1): 54-59.

Pillai, R.R., Elango, R., Ball, R.O., Kurpad, A.V., and Pencharz, P.B. 2015. Lysine requirements of moderately undernourished school-aged Indian children are reduced by treatment for intestinal parasites as measured by the indicator amino acid oxidation technique. J. Nutr. 145(5):954-959. doi: 10.3945/jn.114.208439.

Rafii, M., Chapman, K., Owens, J., Elango, R., Campbell, W.W., Ball, R.O., Pencharz, P.B., and Courtney-Martin, G. 2015. Dietary protein requirement old female adults over 65 years determined by the indicator amino acid oxidation technique is higher than current recommendations. J. Nutr. 145(1): 18-24.

Stephens, T.V., Payne, M., Ball, R.O., Pencharz, P.B., and Elango, R. 2015. Protein requirements of healthy pregnant women during early and late gestation are higher than current recommendations. J Nutr. 145(1):73-8. doi: 10.3945/jn.114.198622. 
Tang, M., McCabe, G.P., Elango, R., Pencharz, P.B., Ball, R.O., and Campbell, W.W. 2014. Assessment of protein requirement in octogenarian women using the indicator amino acid oxidation technique. Am. J. Clin. Nutr. 99(4): 891-898.

Tian, Y., Liu, J., Zhang, Y., Piao, J., Gou, L., Tian, Y., Li, M., Ji, Y., and Yang, X. 2011 Examination of Chinese habitual dietary protein requirements of Chinese young female adults by indicator amino acid method. Asia Pac. J. Clin. Nutr. 20(3):390-396. 